\title{
Ecofriendly Technologies for Disease and Pest Management in Mulberry-A Review
}

\author{
N. Vijaya Kumari \\ Dept.of Sericulture, S.P.M. University, Tirupati.
}

\begin{abstract}
Mulberry belonging to the Genus Morus is extensively grown in South India where most of the sericulture industry is concentrated.Mulberry the main food sourse of silkworm Bombyx mori.L is a perennial plant. Since mulberry leaf is available throughout the year, it makes the plant prone to various diseases and pests. Various pathogens like fungi, bacteria,viruses and nematode cause diseases in mulberry. Among the pests few sap suckers and defoliators are considered to be major as they cause extensive damage to the mulberry. These diseases and pests cause around 12-25\% leaf yield loss either by depletion in nutritive value or defoliation. Feeding these inferior quality leaf adversely affect the silkworm growth and finally the silk industry. To manage or control these diseases and pests a number of management strategies are followed which include physical, chemical and biological methods. Among these synthetic chemicals are commonly used and which are more effective, but continuous usage of chemicals cause environmental pollution resulting in adverse effects on soil flora,fauna and also human health due to residual toxicity. But many times the situation forces the farmer to depend on these synthetic chemicals which are not only costly but also unsafe on environment. So, there is a great need to think of environmentally safe methods for managing pests and diseases. In this review cum case study paper an attempt was made to discuss in brief about various disease and pests of mulberry and their management techniques and highlighting the important ecofriendly management strategies, their merits and demerits.This review cum research article will elucidates the research conducted on disease and pests and their management strategies in mulberry for better quality leaf production .
\end{abstract}

Key words: ecofriendly techniques,mulberry,diseases,pests

Foliar diseases

\section{Major Diseases Of Mulberry And Their Managent:}

Mulberry is mainly affected by five foliar diseases, they are Leaf spot,Leaf rust,Powdery mildew, Leaf blight and Bacterial blight,

1. Leaf spot disease: It is one of the major diseases of mulberry caused by a fungal pathogen Cercospora moricola. This disease is common in rainy and post rainy seasons(July -December) in south India.The symptoms of this disease are irregular brownish spots surrounded with chlorotic rings and as the disease advances the spots enlarge and coalesce and the dead tissue fall off resulting in shot hole development. This disease causes 10-12\%leaf yield loss(Sharma et al 2009).

\section{Management:}

Synthetic Fungicide:Bavistin(Carbendazim 50\%WP) solution @ 2\%concentrations recommended which reduces up to $70 \%$ of the disease.The safe perioduse the leaf for feeding of silkwormis 2-3 days(Srikantawamy etal.,1998)

Ecofriendly approaches:Biocontrol agent Trichoderma harzianum(Th-1) and Trichoderma pseudokoningii (Tp) were found to be effective against Brown spot disease(Sharma and Gupta,2000)Leaf extracts of Eucalyptus spp. and Calotropis gigantia also found to be effective (Sarvamangala et al,1993)

2. Powdery mildew: This disease is one of the major foliar diseases caused by Phyllactina corylea (Pers).Karst which is also known as P.moricola (P.Henn.)Homma (Takamatsu etal., 1982).It is more prevalent in tropics and temperate regions during post rainy and winter seasons. The symptoms of this disease is white powdery patches on the lower surface of the leaf and as the disease advances the entire leaf turn to brownish black and fall off prematurely.The loss due to mildew is around $12 \%$ besides causing depletion in nutritive value(Teotia and Sen,1994;Qadri et al.,1998)

\section{Management:}

Synthetic chemicals: $2 \%$ Bavistin and 0.2 Karathane are effective fungicides.

Ecofriendly approaches:Natural enemies like Yellow lady bird beetles,Illeis cincta Fab and I.indica Timb have been reported as predators of P.corylea conidia and mycelia .The fungus P.corylea does not regenerate on the leaves which are predated by beetles.(Reddy et al 1989,Kumar and Chowdary ,2001).A fungal hyperparasite 
Cladosporium spp also reported to be hyperparasitic on conodiophores and conidia of P.corylea(Rao and Sullia,1981)

11.Leaf Rust: There are two types of rust diseases which are common in Mulberry.They are black rust and red rust .Black rust is caused by Cerotelium fici (Cast).Arthur and also known as Peridiospora mori Barclay (Prasad et al., 1993) Red rust is caused by Aecidium mori(Sydow \& Butler) Barclay.This disease causes up to 15\% leaf loss (Sundareswaran et al.,1988,Teotia and Sen,1994;Pratheesh Kumar et al .,2000)The Symptoms of black rust disease are circular pin head sized blackish brown spots.Red rust affects young buds,leaves and petioles and shoots.The symptoms are young buds become swollen with upward curling, protruded golden yellow spots. Management: Fungicide Kavach $0.2 \%$ is recommended.

Ecofriendly approaches :Leaf extracts of Adhatoda Zeylanica and Azadirachta indica are found to be effective against rust diseases.

Bioagents Trichoderma harzhianum and T.pseudokoningii were found to be effective aginst rust.

Fungal leaf Blight: This disease is caused by various species of fungi Alternaria alternata( $\mathrm{Fr}$. $)$ Keissler,Fuasrium pallidorosium (Cooke)Sac..It reduces up to $10 \%$ leaf yield loss with depletion in nutritive values.The symptoms of the disease are blackening of leaves from the tip or edges of lamina. As the disease advances the entire leaf surface is affected and fall off prematurely.

Management: Chemical control by the application of $0.2 \%$ Dithane M- 45 has been found effective against leaf blight.

Ecofriendly approaches:Trichoderma harzianum is found to be effective against Blight disease.

Bacterial blight:It is caused by Pseudomonas syringe pv.mori Boyer \& Lambert)Young, .This disease is more common in rainy and winter seasons and it causes about $8-12 \%$ leaf yield loss. The symptoms of this disease are numerous water soaked spots which deteriorates nutritive value.

\section{Management:} effective.

Agricultural antibiotics Streptomycin ,Tetracyclin are effective. Dithane M45 is also found to be

Ecofriendly approaches:Leaf extracts of neem which is commercially available as Azhadirachtin $0.15 \%$ is effective.Bioagents like Pseudomonas fluorescences and Trichoderma harizhianum are found to be effective.

\section{Stem And Root Diseases}

Stem canker (NURSERY DISEASE): This disease is caused by a fungus Botryodiplodia theobromae Pat which is characterized by greenish black eruptions on cuttings .This is a major problem in nurseries which causes rotting of the whole cutting. This diseas causes around $40-45 \%$ loss.

Management:Treating the cuttings or dressing the stem cuttings with synthetic fungicide Dithane M-45 is recommended.

Ecofriendly approaches:Biocontrol formulation containing Trichoderma pseudokoningii at the rate of $2 \mathrm{gm} / \mathrm{m}^{2}$ is recommended.

Root rot:This is one of the most dangerous diseases of mulberry plants as it kills the whole plant suddenly causing severe damage.It is caused by a fungus Fusarium solani and Fusarium oxysporum. The loss due to this disease is $30-40 \%$.This disease is characterized by sudden wilting of leaves due to rotting of the root system and death of the plants.

Mangement:

Dipping the saplings in $0.1 \%$ Bavistin solution for an hour and dusting of Dithane M-45 in the pits before plantation is recommended

\section{Ecofirendly approaches:}

Biocontrol formulation called Raksha containing T.harizhianum and integrated with another boformulation of Pseudomonas flourescens is recommended@ $500 \mathrm{~g} / \mathrm{plant}$.

\section{Root knot :}

Another major root disease is root knot caused by a nematode Meloidogyne incognita.This disease is characterized by the galls/knots on the root system which is characteristic symptom.It results in stunted growth and reduced yield and many times it makes a way for the entry of root rot causing pathogen resulting in death of plants.It causes up to $12 \%$ loss.

Management: Nematicides like Furadon 3G @ 40 kg/ha/year or Rugby 10G @30kg/ha/year in four split doses is recommended.(Govindaiah et al)

Ecofirendly approaches: Biocontrol formulation containingVerticillium chlamidosporium along with neem oil cake and FYM(1:24:200)@ 200gm/plant is recommended at three splitdoses.(Sharma et al ) 
MAJOR PESTS OF MULBERRY:Being a perennial evergreen and high biomass producing plant,mulberry facilitates ideal conditions for uninterrupted and rapid multiplication of pests which is reaching alarming proportions. About 300 species have been reported from different parts of the world on mulberry(Nailk,1997) The pests of mulberry are classified in to two categories 1.Sap suckers 2.Defoliators

The major sap suckers are 1, Pink mealy bugs(Meconelli coccus hirsutus),Spiralling white fly(Aleurodicus dispersus Russel) and the recently identified Papaya mealy bug (Paracoccus sp) and the defoliators are Bihar hairy caterpillar(Spilosoma oblique),Leaf webber(Diaphania puverulentlis).

Pink mealy bug (Meconellicoccus hirsutus Green): It is a major pest of mulberry which is hard to kill pest..This pest is highly prevalent in tropical regions and has wide host range.The feeding injury of this pest results in crinkling and distortion of leaves and stunted growth in the apical shoot resulting in malformation.These symptoms are collectively called as Tukra disease which deteriorates leaf quality and quantity resulting in cocoon crop loss.The loss due to this pest is more than $30 \%$ which some times reaches $50 \%$ also.

Mangement:Since it is hard to kill pest no single method is effective in reducing the severity of this pest infestation but an integrated approach in combination of Physical, chemical and biological methods work better against this pest.

Chemical pesticide:DDVP or Dichlorovas or Nuvan at $0.15 \%$ in $0.5 \%$ soap solution after pruning or leaf harvest twice with an interval of 10 days with 15 days safe period to feed the silkworm.(Anonymous 2000).

Ecofriendly approaches: Aqueous solutions of neem and pongamia leaves (2\%) is found to be effective against the crawlers (Varghese and Tandon(1987).Eucalyptus globulus, Ocimum sanctum and Piper betle leaf extracts also found to be effective.

Natural enemies:A number of coccinellid predators are known to predate mealy bug.Among them Cryptolaemous montrouzieri Mulsant(Australian Lady bird beetle) and Scymnus coccivora Ayyar which is native coccinellid predator are found to regulate mealy bug population. Cryptolaemus montrouzieri Mulsant at the rate of 250 adults in two doses of each 125 in the months of January-February and September-October as a componenet of integrated management is suggested by Rajadurai(2005)Field release of S.coccivora @8 beetles $/ \mathrm{m}^{2}$. is found to suppress mealy bug population(Palanidurai,1996)

Bihar hairy caterpillar(Spilosoma oblique):It is a sporadic pest of mulberry occurring during pre monsoon and monsoon period in southern sericultural states. This pest is voracious feeder of mulberry leaf leaving only veins. The loss due to defoliation is up to $40 \%$.

Management :Spraying of $0.15 \%$ DDVP twice at weekly intervals is found to be feffcetive.

Bilogical control : Release of an egg parasitoid Trichogramma chilonis @ 1 lakh adults (5 tricho cards)/acre at an interval of 3 days is found to be effective in reducing hairy caterpillar population(Katiyar etal 1999)

Custard apple formulations(Annona squamosa) were found to be effective against hairy caterpillar .Annona oil based formulations and Annona seed extracts and leaf based formulations were proven to be potential botanical pesticides to suppress bihar hairy caterpillar(Raman et al.,2000)

Leaf webber or Leaf roller(Diaphania pulverulentalis):The incidence of this pest has become more severe in the recent years during rainy and winter seasons in south Indian conditions with high percentage of incidence(Sengupata et al.,1990Rajadurai et al 1999).The loss due to this pest is around 30\%. The young larvae feed on the tender unopened leaves and they bind or roll the leaves by secreting silky threads. The larvae feed on the leaves on reduce leaf yield.Especially tender leaves become scarce as the pest attack mainly the tender leaf. Management:

Foliar application of pesticide DDVP @ $0.076 \%$ in two to three times with 10 days interval is recommended.

\section{Ecofriendly approaches:}

Natural enemies: Release of Trichogramma chilonis-egg parasitoid @ 1 lakh adults/acre in four split doses is found to be effective.Other natural enemies like Apanteles sp. and Chelonus sp were also found to be parasitic on leaf webber.(Geetha Bai et al.,1997,Srinivasa gowda etal 2001).The larval predator Calosoma sp.also found predating leaf webber larvae.(Annon..1998)

Aqueous leaf extracts of Catheranthus roseus,Ocimum sanctum,Piper betle,Mentha piperita and Tagetus patula were reported to be potential against webber larvae.

Spiraling whitefly and Papaya mealy bug - New threats to mulberry. 
Spiralling white fly(Aleurodicus dispersus Russel):This pest was identified on mulberry a decade back and was considred as minor pest since its incidence was not severe but in the recent past i.e since two years the pest infestation has become severe in mulberry as well as many plantation and horticulture crops and causing serious damage .This pest is a sap sucker which causes chlorosis,yellowing,and leaf fall. High population of whiteflies feeding on nutrients of plants affect the plants physiological process ultimately causing leaf shedding and reduced growth rate.Chlorotic spots appear at feeding sites on leaf surfaces. Vast amount of honey dew produced by nymphs leads to mould development on leaves and adversely affects photosynthesis (Sundararaj etal.2000) All the life stages of whiteflies are hard to control with conventional insecticides because of rapid multiplication their preferred habitat on the under surface of leaves, thereby not being easily targeted by direct hit of spraying insecticides.

Management: The pest can be effectively managed by applying Triazophos $40 \mathrm{EC}$ at 0.06 per cent or Dimethoate $30 \mathrm{EC}$ at 0.05 per cent in two split doses.

\section{Ecofriendly approaches:}

Neem oil and cotton seed oil at 0.01 per cent were also found to cause considerable mortality of the different stages of the pest.(Marium and Chandramohan 2000).Extracts of Ocimum bacilicum and Coleus aromaticus @ 2-4\% are potential against nymphal and adult mortality(Jagadish etal., 2001)

Natural enemies: Aphelindae parasites like Encarsia guadeloupae, Encarsia haitiensis Dozier are found to be potential against whiteflies.

Predators like Cryptolaemus montouzierii @300 adults/acre and Menochilus sexmaculatus @200adults/acre are found to be effective.

Papaya mealy bug (Paracoccus marginatus):papaya mealybug, Paracoccus marginatusWilliams and Granara de Willink, were first observed infesting papaya in the central(Kahului) area of the island of Maui in early May2004,.

Papaya mealy bug is a polyphagous sucking insect pest and has been recorded on more than sixty host plants in India.But its serious attack was recorded only in a few economically important crops such as papaya, mango, pomegranate, citrus, beans, tomato, potato, pepper and cotton. In other plants it exists as a minor pest.However sudden outbreak of any minor pest is common owing to various reasons. The recent trend in the population built-up of papaya mealy bug on mulberry, the sole food plant of silkworm, indicates its emerging pest status especially in South India where mulberry is cultivated intensively.

Papaya mealy bug infestation is typically observed as clusters of cotton like masses on tender stem and veins of mulberry leaves as the insect secretes a white waxy coat over its body.The adult female lays 100-600 eggs which hatch into nymphs in about ten days. The nymphs crawl actively to search for feeding sites and settle in clusters on leaves and stems.

The mealybug injects a toxin as it feeds on leaves and fruit which results in chlorosis (yellowing), stunting, deformation, early leaf and fruit drop, and buildup of honeydew.Sooty mold growing on honeydew excreted by the mealybugs interferes with photosynthesis.Heavy mealybug infestations may kill plants

The pest completes one generation in a month. The symptoms appear on the leaves as chlorosis (yellowing), deformation and premature drop. Hence, feeding with papaya mealy bug infested mulberry leaves adversely affects the growth of silkworm and silk production.

\section{Management :}

Planting of highly susceptible host plants such as papaya or hibiscus in the vicinity of mulberry garden should be avoided.

Plugging of the infested twigs and leaves and their burning during early stage of infestation is the best method of eradication of the pest.

Spraying dimethoate ( 0.05 per cent) controls the pest effectively. Leaves can be fed to silkworms 15 days after spraying the insecticide.Indiscriminate use of insecticides in mulberry fields should also be avoided as they induce resistance in the pests and destroy its natural enemy population.

\section{Ecofreindly approaches:}

Release of Cryptolaemus montrouzieri, an effective predatory ladybird beetle at 125 adults per acre twice a year at the interval of six months keeps the pest population suppressed.The tiny parasitic wasps Anagyrus loecki,Pseudleptomastix mexicana and Acerophagus papaya are found to control Paracoccus.

Botanical pesticides like neem oil and other organic pesticides like fish oil, and rosin soap are effective.

\section{Case Study:}




\section{Survey On Whitefly:}

A survey was conducted on the incidence of Spiraling white fly(Aleurodicus dispersus Russel )on mulberry during the years 2008-2009 and 2010.It was found that this incidence of whitefly on mulberry was first time in Rayalaseema region of Andhra Pradesh especially in Chittoor District.It was noticed that white fly infestation was severe in mulberry where it is grown as avenue tree especially when the main hosts of whitefly like Guava,hibiscus,Casava are in the vicinity of mulberry.In these studies the intensity of white fly infestation on mulberry,Guava,Hibiscus,Casava,Jackfruit and also Pongamia was studied by counting the number of egg spirals per leaf, number of eggs per spiral and number of adult flies. It was found that the severity is high in Guava follwed by Mulberry.

So,This study is alarming the possible major threat of white fly to mulberry in future and the need of the studies to identify the appropriate and potential management strategy.

Studies are in progress to estimate the economic loss due to white fly in mulberry and in Guava and also studies are in progress to identify the natural enemies of white fly and botanical pesticides to manage this pest.

\section{Biological Agent Against Powdery Mildew Fungus}

Another important work done was identifying the natural enemy on Powdery mildew fungus Phyllactinai corylea.During November 2009 to January 2010 a natural enemy was identified feeding on the conidia of Phyllactinia fungus.It was identified as Illeis cincta Fab It was reported in very few places in India. To study the predation rate of the beetle the number of conidia before feeding and after feeding by the yellow beetle was studied and the life cycle of this yellow beetle was also observed.Stuides are being done to culture and formulate biocontrol agent yellowbeetle.

\section{Conclusion:}

Eco friendly technologies for the management of various pest and diseases is gaining momentum in recent past because of the adverse effects of synthetic chemicals which are increasing environmental pollution and destroying flora and fauna and human health on the earth. Because of these reasons fascination for exploring new alternative management techniques by using eco friendly products and exploiting antagonism has developed among the researchers, It is the responsibility of man to reduce pollution and save the earth by making use of environment friendly methods to combat against pets and diseases.

In the above paragraphs various pests and diseases of mulberry and their management methods were discussed in a nutshell.Among the various ecofriendly methods discussed above few are specific to some pests and diseases and some are common .

So, an appropriate method should be selected for effective control of a disesase or pest. But many times when the intensity of a disease or pest is severe chemical control may become must which can be used in combination or as integrated management to reduce its toxicity level.

\section{References:}

[1] Anonymous(1997).Bionomics and integrated control of of Spilosoma oblique and other important lepidopteran mulberry pests.Annual report,Cwntral Sericultural Research and Training Institute,Pampore,India pp:86-91.

[2] Geetha bai,M.,Marimadaiah,B.,Narayana Swamy,K.C.Raj gopal.(997).An outbreak of leaf roller pest Diaphania (Margorania)pulverulentalis 9Hampson)on mulberry in Karnataka Geobios news reports.16(2):73-79.

[3] Govindaiah,Dandin,S.B.,Sharma,D.D. \& Datta R.K(1993) Efficacy of different doses of Carbofuran on Meloidogyne incognita infesting mulberry,Indian J.Seric.32,99-101

[4] Jagadish,K.S.,Narayana swamy,K.C.,Naika R.,Manjuntha Gowda\& Shivakumar .,H.R.,(2001).Bioefficacy of certain plant based insecticides against spiraling whitefly,Aleurodicus disperses Russel infesting mulberry.In :Abstracts of Natl.Sem.on Mulberry sericulture Research in India,KSSRDI,Thalagattpura,Bangalore,India.26-28,November,p.194-195

[5] Katiyar.,R.,L.,,Yogananda,M.C.,Manjunatha,D.,Senn,A.K.,Asshen,M.M.and Datta,R.K.(1999).Role of Trichogramm chilonis (Ishii)in the suppression of field population of the Bihar hairy caterpillar,Spilosoma obliqua Walker,Indian .J.Sericulture,38:40-43.

[6] Kumar.,V.,\& Chowdary,N.B.,(2001).Illeis indica -A potential biocontrol agent to check the menace of powdery mildew on mulberry.Indian Farming,51(4),32-34.

[7] Mariam M.A.,\&Chandramohan,N.,(2000).Evaluation of chemical insecticidesand botanicals against various stages of spiraling whitefly(Aleurodicus disperses Russel)on mulberry. The Madras Agricultural journal,87(7-9)379-381.

[8] Naik (1997).Bioecology of thrips infesting mulberry.MSc.Thesis ,University of Agricultural Sciences,Bangalore,pp.76

[9] Palanidorai.,S.,(1996)Ecology and management of pink mealy bug,Maconellicoccus hirsutus Green in mulberry.MSc(Seri)Thesis.Tamilnadu agricultural university,Coimbatore,pp 74

[10] Prasad,K.V.,Dayakar Yadav,B.R.,\&Sullia,S.B.(1993) Taxonomicstatus of rust on mulberry in India.Current Sci.65,424-426

[11] PrateeshKumar.,P.M.,.,Maji.,M.D..,Gangavar,S.K.,Das,N.K.,\&Saratchandra,B.,(2000).Development of leaf rust (Peridiospora mori) and dispersal of urediospores in mulberry (Morus spp).Internationa.J.Pest management,46,195-200,

[12] Qadri,S.M.H.,PrateeshKumar,P.M.,Gangavar,S.K.,Elangovan,C.,Maji,M.D.,\&Sarathchandra,B.,(1998).Crop loss assessment due to powdery mildew in mulberry.Bull.Seric., 9,31-35.

[13] Rajadurai,S.,(2005)Ladybird beetle-A potential biocontrol agent for mulberry mealy bug.Indian Silk ,44(5):5-7.

[14] Raman G.V.,Rao,M.S.,Srimannarayana G\& b.Venkateswarulu (2000).Bio efficacy of custard apple (Annona squamosa)formulations aginst mulberry pest,Bihar hairy caterpillar(Spilosoma oblique Walker)and mulberry silkworm 9Bombyx mori.L).Sericologia 40(2) 267-273.

[15] Rao,S.S.,\& Sullia,S.B.,(1981).,A hyperparasite of Phyllactinia corylea,the powdery milde of mulberry.Cur.Sci.,50,769. 
[16] Reddy D.N.R.,Kotikal .,Y.K.,Rayudu,B.V.S.(1989).Development of Illeis cincta on mulberry powdery mildew Phyllactinia corylea infecting Morus alba.,Science and Culture,55,111-112.

[17] Sarvamangala,H.S.,Govindaiah \& Datta ,R.K.(1993).Evaluation of plant extracts for the control of fungal diseases of mulberry.Indian Phytopathology.46,398-401

[18] Sengupta,A.K.,Kumar,P.,Baig,M.Govindaiah(1990).Hand book of pests and disease control of mulberry and silkworm.ESCAP,Thailand,p:88

[19] Sharma ,D.D.,Gupta,V.P.,(2000)Evolution of antagonistic microbes and development of biocontrol method for leaf spot and leaf rust diseases of mulberry.In :Annual report(1999-2000)Central Sericultural Research and Training Institute,Mysore,India,36,57-61

[20] Sharma ,D.D.,V.Nishita Naik,N.B.Chowdary,Mala V.Rajan \& C.K.Kamble (2009).Management of mulberry diseases through Ecofriendly approaches - A review.Sericologia vol.49, pp.123-135

[21] Srikantaswamy.,K.,Gupta,V.P.,Gunasekhar.,V.,Renukeswarappa.,J.P(1998).Evaluation of fungicidal control of leaf spot and powdery mildew diseases of mulberry at farmer's fields.Indian J.Seric.,37(2),159-161.

[22] Srinivas Gowda.,T.K.,Narayana Swamy \&V.T.Sanaveerappanavar(2001)Natural enemies of Diaphania pulverulenralis (Hamson)Lepidoptera:Pyralidae )infesting mulberry. Sericologia 41(4) 625-621

[23] Sundareswaran .,P.,Govindaiah,Srinivasan,E.B.\&Jolly.,M.S.,(1998)Effect of leaf rust disease on the nutritive omposition of mulberry(Morus albaLOIndian J.Seric.27,159-160.

[24] Takamatsu,S.,Ishizaki,H.,\&Kunoh,H.,(1982).Scanning electron microscopy on perithecia of powdery mildew fungi.111.Perithecial development in mulberry powdery mildew,Phyllactinia moricola,Trans.Mycol,Soc.Japan 23,279-286.

[25] Teotia.,R.S.,\& Sen,S.K.(1994).Mulberry diseases in India and their control-a preview,Sericologia,34,1-19 